[Chem. Pharm. Bull.

35(12)4711-4716(1987)

\title{
Reaction of Cyclic Phosphites with Haloacetones
}

\author{
Iwao Morita, ${ }^{*}$ Masami Tsuda, Masahiro Kise, \\ and MaKoto SUgIYAMA
}

Research Laboratories, Nippon Shinyaku Co., Ltd., Nishiohji-hachijo,

Minami-ku, Kyoto 601, Japan

(Received May 12, 1987)

\begin{abstract}
Treatment of various cyclic phosphites (1), e.g., 2-methoxy-1,3,2-dioxaphosphorinane (1a), 2methoxy-5,5-dimethyl-1,3,2-dioxaphosphorinane (1b) and 2-methoxy-1,3,2-dioxaphosphorane (1c), with haloacetones (2) gave cyclic Arbuzov products (3), cyclic Perkow products (4), cyclic methylphosphonates (5), and acyclic products (6-8). Compound 1a gave all of the products (3a, 4a, 5a, 6ag, 7ag, 8ag). However, cyclic phosphites with substituents in the ring (1b, 1d) gave only the cyclic products $(3-5)$. The five-membered ring phosphite (1c) yielded only the acyclic products $(6 \mathrm{cg}, 7 \mathrm{cg})$. Treatment of $1 \mathrm{a}$ with chloroacetone gave only the Perkow products (4a, 7ah). Cyclic phosphite (1f) with a 2-benzyloxy substituent afforded simply the cyclic products (3a, 4a, 9). A mechanistic interpretation of these reactions is presented.
\end{abstract}

Keywords—— — cyclic phosphite; haloacetone; cyclic acetonylphosphonate; cyclic enol phosphate; Arbuzov reaction; Perkow reaction

In organophosphorus chemistry, it is well known that trialkyl phosphites react with $\alpha$ halocarbonyl compounds to give enol phosphates (the Perkow reaction ${ }^{1)}$ ) and/or 2-oxoalkylphosphonates (the Arbuzov reaction ${ }^{2)}$ ). Both reactions depend on the nature of the compounds and the conditions employed. The 2-oxoalkylphosphonates obtained by means of the Arbuzov reaction can serve as useful synthetic intermediates for the synthesis of $\alpha, \beta$ unsaturated ketones. ${ }^{3)}$ However, cyclic phosphites have not been reported to react with $\alpha$ halocarbonyl compounds. We previously reported ${ }^{4,5)}$ syntheses of cyclic acetonylphosphonates which were key intermediates of 1,4-dihydropyridine-5-cyclic phosphonates with calcium antagonistic activity. We now describe the reaction of cyclic phosphites with $\alpha$ haloacetones.

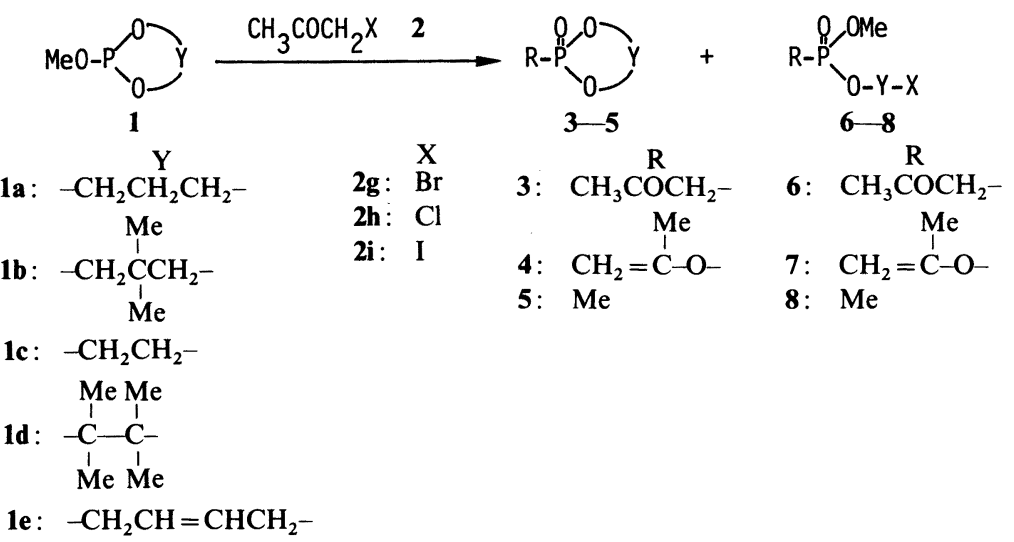




\section{Results and Discussion}

In the usual Arbuzov reaction, haloacetones are added to trialkyl phosphites heated to $80-120^{\circ} \mathrm{C}$. The reaction of the cyclic phosphite (1a) with bromoacetone was carried out under the same conditions (method A) to afford the cyclic methylphosphonate (5a), the acyclic products (6ag, 7ag, 8ag), which are not obtained from trialkyl phosphites, plus the acetonylphosphonate (3a) (an Arbuzov product) and the enol phosphate (4a) (a Perkow reaction product).

The cyclic phosphite (1b), with two methyl groups at the 5-position, yielded the cyclic methylphosphonate $(\mathbf{5 b})$, and other normal products but no acyclic products. In the reactions of cyclic phosphites with alkyl halides, the cyclic phosphites were less reactive than the acyclic phosphites. ${ }^{6}$ The above results, however, suggest that the cyclic phosphites (1) are more reactive than the trialkyl phosphites, because 1 formed 5 and 8 . Therefore, to avoid the formation of $\mathbf{5}$, the reaction was carried out at room temperature or below with a mixture of $\mathbf{1}$ and bromoacetone, in which an exothermic reaction occurred (method B). In method B, the yields of the acetonylphosphonates (3) and the enol phosphates (4) were increased about 1.2 and 1.6-1.7 times, respectively, but that of the methylphosphonates (5) was decreased to onethird. The yield of acyclic products was unaffected. In the same manner as in method B, the reaction of various cyclic phosphites $(\mathbf{1 a}-\mathbf{f})$ with haloacetones $(\mathbf{g}-\mathbf{i})$ was carried out. These results are summarized in Table I.

The reaction of 2-methoxy-1,3,2-dioxaphosphorane (1c) (five-membered ring) with bromoacetone afforded only the acyclic products $(\mathbf{6 c g}, 7 \mathrm{cg})$; the cyclic acetonylphosphonate (3c) was not obtained, presumably because of the instability of its ring. However, 4,4,5,5tetramethyl-1,3,2-dioxaphosphorane (1d) afforded the cyclic acetonylphosphonate (3d) in $53 \%$ yield, and no acyclic products were obtained. The phosphite (1e) (seven-membered ring) gave mainly the acyclic products (6eg, 7eg), with acetonylphosphonate (3e) as a minor product $(10 \%)$.

On the other hand, the reaction of 1a with chloroacetone by method $\mathrm{B}$ gave mainly the enol phosphate (4a) in $70 \%$ yield; the acetonylphosphonate (3a) was scarcely detected. In the reaction with iodoacetone, la yielded the same products as with bromoacetone, but in different ratios; that is, the yield of Arbuzov products was $50 \%$ more and that of the Perkow products was $29 \%$ (compared to method B) less than with bromoacetone.

When 2-benzyloxy-1,3,2-dioxaphosphorinane (1f) was used instead of 1a, although

TABLE I. Products of the Reaction of Cyclic Phosphites with Haloacetones

\begin{tabular}{|c|c|c|c|c|c|c|c|c|c|c|}
\hline \multirow{2}{*}{ Run } & \multirow{2}{*}{$\begin{array}{c}\text { Phosphite } \\
1\end{array}$} & \multirow{2}{*}{$\begin{array}{c}\text { Haloacetone } \\
\text { X }\end{array}$} & \multirow{2}{*}{ Method $^{a)}$} & \multicolumn{7}{|c|}{ Product } \\
\hline & & & & 3 & 4 & 5 & 6 & 7 & 8 & 9 \\
\hline 1 & $1 a$ & $\mathrm{Br}$ & A & 27 & 24 & 25 & 11 & 3 & 8 & \\
\hline 2 & $1 a$ & $\mathrm{Br}$ & B & 33 & 38 & 8 & 11 & 3 & 3 & \\
\hline 3 & 1b & $\mathrm{Br}$ & A & 45 & 20 & 22 & - & - & - & \\
\hline 4 & $1 b$ & $\mathrm{Br}$ & B & 55 & 35 & 7 & - & - & - & \\
\hline 5 & 1c & $\mathrm{Br}$ & B & - & - & - & 42 & 18 & - & \\
\hline 6 & 1d & $\mathrm{Br}$ & B & 53 & 22 & Trace & - & - & - & \\
\hline 7 & 1e & $\mathrm{Br}$ & B & 10 & - & - & 17 & 3 & - & \\
\hline 8 & $1 \mathrm{a}$ & $\mathrm{Cl}$ & B & - & 70 & - & - & 8 & - & \\
\hline 9 & $1 \mathrm{a}$ & I & B & 51 & 9 & 15 & 8 & - & 1 & \\
\hline 10 & 1f & $\mathrm{Br}$ & B & 37 & 41 & & & & & 12 \\
\hline
\end{tabular}

a) See Experimental. 


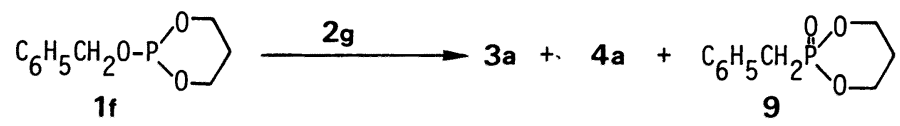

Chart 2

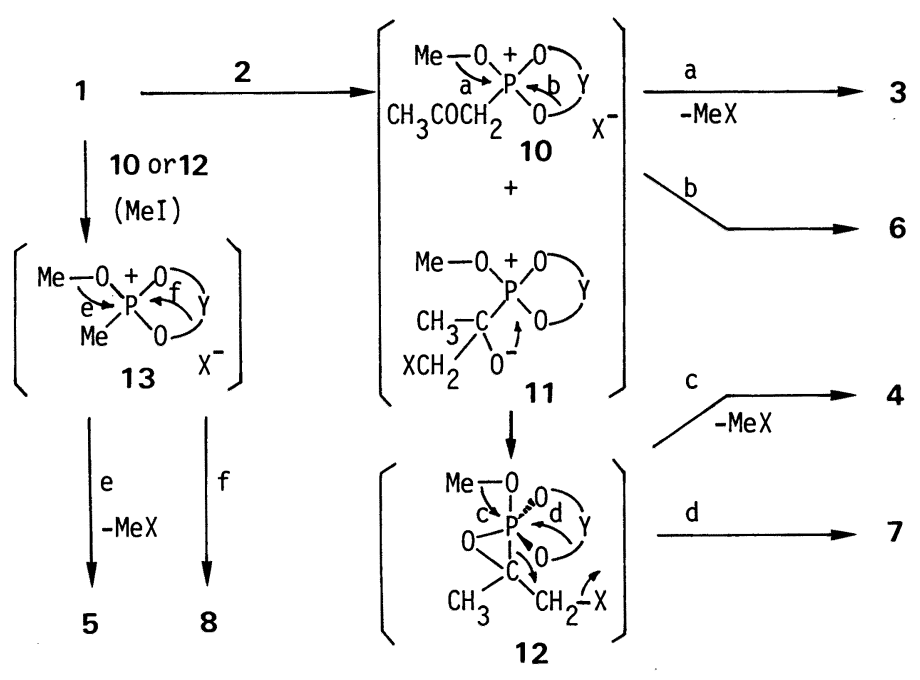

Chart 3

acyclic products were scarcely detected, the formation of 3a was slightly increased because of the increase of the benzylphosphonate (9) and the decrease of the total yield.

Several mechanisms which would account for concomitant Arbuzov and Perkow reactions have been reported from a number of laboratories. ${ }^{7-9}$ ) The mechanism of the Perkow reaction is especially complex, with more than one mechanism often being involved. Among the proposed mechanisms, we are interested in that suggested by Borowitz et al., $\left.{ }^{8}\right)$ which involves the initial attack of a phosphite on the carbonyl carbon followed by the formation of a three-membered-ring intermediate compound, and in that of Gillespie et al., ${ }^{9}$ ) which involves a penta-coordinate phosphepane intermediate. The reaction mechanism of the cyclic phosphites (1) with haloacetones may be represented by a modification of Borowitz's mechanism (Chart 3). The phosphonium salt (10) and/or the adduct (11) is first formed, then 10 gives the cyclic acetonylphosphonate (3) through path a and the acyclic product (6) through path $b$, and the phosphonium adduct (11) gives the enol phosphate (4) and the acyclic enol phosphate (7) via a quasi-three-membered-ring transition state (12).

The methylphosphonates $(5,8)$ were supposed to be formed from the phosphonium salt (13), which in general could be obtained from the reaction of 1 with methyl halides. However, 1a was recovered unchanged when a mixture of 1a and excess methyl bromide was heated for a long time at atmospheric pressure. No formation of $\mathbf{5}$ or $\mathbf{8}$ was observed. This result suggests that 13 was not formed by the reaction with methyl bromide, but was formed by reaction with some other methylation agent, such as the intermediate (10 or 12).

In the reaction of $\mathbf{1 a}$, all the products in Chart 3 are formed. In the reaction of $\mathbf{1 b}$, the absence of the acyclic products $(6,7,8)$ suggests that $\mathrm{Br}^{-}$in the intermediates $(10,12,13)$ does not attack a carbon atom in the ring because of steric hindrance by the substituent at the 5position. The exclusive formation of the acyclic products $(6 \mathrm{cg}, 7 \mathrm{cg})$ in the reaction of $1 \mathrm{c}$ with bromoacetone suggests that the reaction proceeds through paths $b$ and $d$ because of the instability of the five-membered ring. The reason why $1 \mathbf{d}$ does not yield acyclic products is 
presumably the steric hindrance by the four methyl substituents. Compound 1e with the seven-membered ring did not yield the enol phosphate (4e) during the reaction, suggesting that the intermediates $(11,12)$ were not formed in considerable amounts in this case, although a small amount of $7 \mathrm{eg}$ could be explained by the intermediary formation of $\mathbf{1 2}$. More experiments are required to elucidate the mechanistic fearures of the reaction in detail.

The effect of the haloacetones differs with the halogen involved. Chloroacetone forms only the carbonyl adduct (11) because of the polarization induced on the carbonyl group by the electronegative $\mathrm{Cl}$ atom to give the Perkow products. With iodoacetone, the greater reactivity of $\mathrm{I}^{-}$leads mainly to the formation of 10 rather than $11 ; 5 \mathrm{a}$ is also increased through 13, which is formed by the reaction of $1 \mathrm{a}$ with methyl iodide. It is known that the cyclic phosphites react with methyl iodide at room temperature. ${ }^{6}$

With a benzyloxy group substituted at the 2-position on the cyclic phosphite, the reaction proceeds through paths a and $\mathrm{c}$ because the dealkylation is much easier in this case than in the methyl derivative.

The effect of temperature on the Arbuzov and Perkow products was the same as in the acyclic phosphite reactions. ${ }^{2)}$

\section{Experimental}

Melting points were determined with a Büchi melting point apparatus and are uncorrected. Infrared (IR) spectra were measured on a Hitachi IR-215 spectrophotometer. Mass spectra (MS) were measured on a Hitachi RMU-6M spectrometer (relative intensity \%). Nuclear magnetic resonance (NMR) spectra were recorded on a Varian YX-200 spectrometer. Chemical shifts are given in $\delta(\mathrm{ppm})$ with tetramethylsilane as an internal standard. The following abbreviations are used: $\mathrm{s}=$ singlet, $\mathrm{d}=$ doublet, $\mathrm{t}=$ triplet, $\mathrm{q}=$ quartet, $\mathrm{m}=$ multiplet, $\mathrm{br}=$ broad. Column chromatography was performed by flash chromatography on Merck silica gel (Kieselgel $F_{254} 60 \mathrm{H}$ ).

Reaction of 2-Methoxy-1,3,2-dioxaphosphorinane (1a) with Bromoacetone-Method A: Bromoacetone (5.48 g, $0.04 \mathrm{~mol})$ was added dropwise to the preheated $\left(60^{\circ} \mathrm{C}\right)$ phosphite $1 \mathrm{a}(5.44 \mathrm{~g}, 0.04 \mathrm{~mol})$ at a rate which kept the temperature at $120^{\circ} \mathrm{C}$ without further heating, with stirring. The reaction mixture was stirred for $1 \mathrm{~h}$ at $70-80^{\circ} \mathrm{C}$ and then cooled. The mixture was chromatographed on silica gel (hexane-AcOEt) to afford a mixture $(3.39 \mathrm{~g})$ of $3 \mathrm{a}(27 \%)$ and $5 \mathrm{a}(25 \%), 4 \mathrm{a}(1.61 \mathrm{~g}, 24 \%)$, a mixture $(1.78 \mathrm{~g})$ of $6 \mathrm{ag}(11 \%)$ and $8 \mathrm{ag}(8 \%)$, and $7 \mathrm{ag}(0.53 \mathrm{~g}, 3 \%)$. The yields $(\%)$ of mixture components were calculated from the NMR spectra (3a: $\mathrm{CH}_{2} \mathrm{COCH}_{3}$ and 5a: $\mathrm{CH}_{3}$. 6ag: $\mathrm{CH}_{2} \mathrm{COCH}_{3}$ and 8ag: $\mathrm{CH}_{3}$ ).

Method B: A mixture of bromoacetone $(5.48 \mathrm{~g}, 0.04 \mathrm{~mol})$ and $1 \mathrm{a}(5.44 \mathrm{~g}, 0.04 \mathrm{~mol})$ was stirred at $10^{\circ} \mathrm{C}$, causing an exothermic reaction in which the temperature rose to $80^{\circ} \mathrm{C}$. When the evolution of methyl bromide gas had almost ceased, the mixture was kept at $60^{\circ} \mathrm{C}$ for $1 \mathrm{~h}$. The reaction mixture was chromatographed on silica gel (hexane-

2-Acetonyl-2-oxo-1,3,2-dioxaphosphorinane (3a) ${ }^{4}$ : Distillation of the mixture of 3a and 5a obtained in method $(3 \%)$, and $7 \mathrm{ag}(0.50 \mathrm{~g}, 3 \%)$.

2-Acetonyl-1-oxo-1,3,2-dioxaphosphorinane (3a) $)^{4)}$ : Distillation of the mixture of 3a and 5a obtained in method B gave 3a $(2.3 \mathrm{~g})$ as a second fraction [bp $\left.158-160^{\circ} \mathrm{C}(0.8 \mathrm{mmHg})\right]$.

2-Oxo-2-(2-propenyloxy)-1,3,2-dioxaphosphorinane (4a): bp $131-134^{\circ} \mathrm{C}(0.3 \mathrm{mmHg})$, colorless oil. Anal. Calcd for $\mathrm{C}_{6} \mathrm{H}_{11} \mathrm{O}_{4} \mathrm{P} \cdot 1 / 2 \mathrm{H}_{2} \mathrm{O}: \mathrm{C}, 38.49 ; \mathrm{H}, 6.46$. Found: $\mathrm{C}, 38.66 ; \mathrm{H}, 6.06$. MS $m / z(\%): 178\left(\mathrm{M}^{+}, 17\right), 139$ (100). IR $v_{\max }^{\mathrm{film}} \mathrm{cm}^{-1}: 1660,1305,1235,1060,1030 . \mathrm{NMR}\left(\mathrm{CDCl}_{3}\right) \delta: 1.70-1.86\left(1 \mathrm{H}, \mathrm{m}, \mathrm{C}_{5}-\mathrm{H}\right), 2.01\left(3 \mathrm{H}, \mathrm{s}, \mathrm{CH}_{3}\right), 2.22-2.48$ $\left(1 \mathrm{H}, \mathrm{m}, \mathrm{C}_{5}-\mathrm{H}\right), 4.35-4.60\left(5 \mathrm{H}, \mathrm{m}, 2 \times \mathrm{OCH}_{2},=\mathrm{CH}\right), 4.81(1 \mathrm{H}, \mathrm{t}, \mathrm{J}=1 \mathrm{~Hz},=\mathrm{CH})$.

2-Methyl-2-oxo-1,3,2-dioxaphosphorinane (5a): Distillation of the mixture of 3a and 5a obtained in method B gave $3 \mathrm{a}(0.3 \mathrm{~g})$ as a first fraction $\left[\mathrm{bp} 118-122^{\circ} \mathrm{C}(0.8 \mathrm{mmHg})\right]$. The oil obtained was crystallized from AcOEt, $\mathrm{mp}$ 98-99 ${ }^{\circ} \mathrm{C}$. Anal. Calcd for $\mathrm{C}_{4} \mathrm{H}_{9} \mathrm{O}_{3} \mathrm{P}: \mathrm{C}, 35.30 ; \mathrm{H}, 6.67$. Found: C, 35.14; H, 7.02. MS m/z (\%): $136\left(\mathrm{M}^{+}, 45\right), 80$ (100). IR $v_{\max }^{\text {film }} \mathrm{cm}^{-1}: 1320,1250,1140,1055$. NMR $\left(\mathrm{CDCl}_{3}\right) \delta: 1.58\left(3 \mathrm{H}, \mathrm{d}, J=18 \mathrm{~Hz}, \mathrm{PCH}_{3}\right), 1.90-2.22(2 \mathrm{H}, \mathrm{m}$, $\left.\mathrm{CH}_{2}\right), 4.12-4.32\left(2 \mathrm{H}, \mathrm{m}, \mathrm{OCH}_{2}\right), 4.45-4.66\left(2 \mathrm{H}, \mathrm{m}, \mathrm{OCH}_{2}\right)$.

3-Bromopropyl Methyl Acetonylphosphonate (6ag): Distillation of the mixture of 6ag and 8ag obtained in method A gave $6 \mathrm{ag}(0.52 \mathrm{~g})$ as a second fraction [bp $\left.134-136^{\circ} \mathrm{C}(0.5 \mathrm{mmHg})\right]$. Anal. Calcd for $\mathrm{C}_{7} \mathrm{H}_{14} \mathrm{O}_{4} \mathrm{P}: \mathrm{C}, 30.79$; H, 5.17. Found: C, 30.50; H, 5.44. MS $m / z(\%): 272\left(\mathrm{M}^{+}, 13\right), 193(100)$. IR $v_{\max }^{\text {film }} \mathrm{cm}^{-1}: 1715,1365,1260,1040,1015$. NMR $\left(\mathrm{CDCl}_{3}\right) \delta: 2.21\left(2 \mathrm{H}, \mathrm{q}, J=7 \mathrm{~Hz}, \mathrm{CH}_{2}\right), 2.34\left(3 \mathrm{H}, \mathrm{s}, \mathrm{COCH}_{3}\right), 3.12\left(2 \mathrm{H}, \mathrm{d}, J=23 \mathrm{~Hz}, \mathrm{PCH}_{2}\right), 3.50(2 \mathrm{H}, \mathrm{t}, J=$ $\left.7 \mathrm{~Hz}, \mathrm{CH}_{2} \mathrm{Br}\right), 3.81\left(3 \mathrm{H}, \mathrm{d}, \mathrm{J}=11 \mathrm{~Hz}, \mathrm{POCH}_{3}\right), 4.18-4.32\left(2 \mathrm{H}, \mathrm{m}, \mathrm{OCH}_{2}\right)$.

3-Bromopropyl Methyl 2-Propenyl Phosphate (7ag): bp 120-123 ${ }^{\circ} \mathrm{C}(0.5 \mathrm{mmHg})$. Anal. Calcd for $\mathrm{C}_{7} \mathrm{H}_{14} \mathrm{BrO}_{4} \mathrm{P}$ : C, 30.79; H, 5.17. Found: C, 29.38; H, 4.93. MS $m / z(\%): 273\left(\mathrm{M}^{+}, 0.9\right), 113(100)$. IR $v_{\max }^{\text {film }} \mathrm{cm}^{-1}: 1660,1280,1250$, 1030, 980. NMR $\left(\mathrm{CDCl}_{3}\right) \delta: 1.97\left(3 \mathrm{H}, \mathrm{s}, \mathrm{CH}_{3}\right), 2.23\left(2 \mathrm{H}, \mathrm{q}, J=6 \mathrm{~Hz}, \mathrm{CH}_{2}=\right), 3.52\left(2 \mathrm{H}, \mathrm{t}, J=6 \mathrm{~Hz}, \mathrm{CH}_{2} \mathrm{Br}\right), 3.84(3 \mathrm{H}$, 
$\left.\mathrm{d}, J=11 \mathrm{~Hz}, \mathrm{OCH}_{3}\right), 4.25\left(2 \mathrm{H}, \mathrm{m}, \mathrm{POCH}_{2}\right) ; 4.54(1 \mathrm{H}, \mathrm{s},=\mathrm{CH}), 4.78(1 \mathrm{H}, \mathrm{t}, J=1 \mathrm{~Hz},=\mathrm{CH})$.

3-Bromopropyl Methyl Methylphosphonate (8ag): 8ag was not purified by the above distillation; therefore it was synthesized from $1 \mathrm{a}$ by reaction with methyl bromide. $1 \mathrm{a}(1.0 \mathrm{~g})$ and methyl bromide $(20 \mathrm{~g})$ were heated in a sealed tube for $3 \mathrm{~h}$ at $100^{\circ} \mathrm{C}$. The reaction mixture was concentrated, and the residue was chromatographed on silica gel (hexane-AcOEt) to afford 8ag $(0.19 \mathrm{~g}, 11.2 \%)$, bp $113-115^{\circ} \mathrm{C}(2 \mathrm{mmHg})$ as a colorless oil. Anal. Calcd for $\mathrm{C}_{5} \mathrm{H}_{12} \mathrm{BrO}_{3} \mathrm{P}: \mathrm{C}, 25.99 ; \mathrm{H}, 5.24$. Found: $\mathrm{C}, 25.43 ; \mathrm{H}, 5.15$. MS $m / z(\%): 151(\mathrm{M}-80 ;-\mathrm{HBr}, 52.5), 111$ (100). IR $v_{\max }^{\mathrm{film}} \mathrm{cm}^{-1}: 1310,1240,1040,1020$. NMR $\left(\mathrm{CDCl}_{3}\right) \delta: 1.50\left(3 \mathrm{H}, \mathrm{d}, J=18 \mathrm{~Hz}, \mathrm{PCH}_{3}\right), 2.20\left(2 \mathrm{H}, \mathrm{m}, \mathrm{CH}_{2}\right), 3.51(2 \mathrm{H}, \mathrm{t}$, $\left.J=6 \mathrm{~Hz}, \mathrm{CH}_{2} \mathrm{Br}\right), 3.75\left(3 \mathrm{H}, \mathrm{d}, J=12 \mathrm{~Hz}, \mathrm{POCH}_{3}\right), 4.11-4.25\left(2 \mathrm{H}, \mathrm{m}, \mathrm{POCH}_{2}\right)$.

Reaction of 2-Methoxy-5,5-dimethyl-1,3,2-dioxaphosphorinane (1b) with Bromoacetone - Method A: Bromoacetone $(5.48 \mathrm{~g}, 0.04 \mathrm{~mol})$ was added dropwise to preheated $\left(70^{\circ} \mathrm{C}\right) \mathbf{1 b}(6.56 \mathrm{~g}, 0.04 \mathrm{~mol})$ at a rate which kept the temperature at $120^{\circ} \mathrm{C}$ without further heating, with stirring. The reaction mixture was stirred for $1 \mathrm{~h}$ at $70-80^{\circ} \mathrm{C}$ and then cooled. The mixture was chromatographed on silica gel (hexane-AcOEt) to afford a mixture $(5.16 \mathrm{~g})$ of $3 \mathrm{~b}$ and $5 \mathrm{~b}(45 \%$ and $22 \%$, respectively) and $4 \mathrm{~b}(1.65 \mathrm{~g}, 20 \%)$.

Method B: A mixture of bromoacetone $(5.48 \mathrm{~g}, 0.04 \mathrm{~mol})$ and $1 \mathrm{~b}(6.56 \mathrm{~g}, 0.04 \mathrm{~mol})$ was stirred at $20^{\circ} \mathrm{C}$, causing an exothermic reaction in which the temperature rose to $120^{\circ} \mathrm{C}$. Work-up as for method $\mathrm{B} 1 \mathrm{a}$ gave a mixture $(4.96 \mathrm{~g})$ of $3 \mathbf{b}$ and $5 \mathbf{b}(55 \%$ and $7 \%$, respectively) and $4 \mathbf{b}(2.32 \mathrm{~g}, 35 \%)$.

2-Acetonyl-5,5-dimethyl-2-oxo-1,3,2-dioxaphosphorinane (3b $)^{4)}$ : Recrystallization of the above mixture (3b and $\mathbf{5 b}$; in method B) from ether gave $3 \mathbf{b}, \mathrm{mp} 91-92^{\circ} \mathrm{C}$.

5,5-Dimethyl-2-oxo-2-(2-propenyloxy)-1,3,2-dioxaphosphorinane (4b): $\mathrm{mp} 69-70{ }^{\circ} \mathrm{C}$ (recrystallization from iso- $\mathrm{Pr}_{2} \mathrm{O}$-ether). Anal. Calcd for $\mathrm{C}_{8} \mathrm{H}_{15} \mathrm{O}_{4} \mathrm{P}: \mathrm{C}, 46.60 ; \mathrm{H}, 7.33$. Found: C, 46.25; H, 7.14. $\mathrm{MS} m / z(\%): 206\left(\mathrm{M}^{+}, 23\right)$,

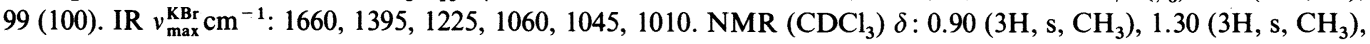
$2.00\left(3 \mathrm{H}, \mathrm{d}, J=1 \mathrm{~Hz},=\mathrm{C}-\mathrm{CH}_{3}\right), 3.84-4.04\left(2 \mathrm{H}, \mathrm{m}, \mathrm{OCH}_{2}\right), 4.14\left(2 \mathrm{H}, \mathrm{d}, J=10 \mathrm{~Hz}, \mathrm{OCH}_{2}\right), 4.51-4.57(1 \mathrm{H}, \mathrm{m}$, $=\mathrm{CH}), 4.79(1 \mathrm{H}, \mathrm{t}, J=1 \mathrm{~Hz},=\mathrm{CH})$.

2,5,5-Trimethyl-2-oxo-1,3,2-dioxaphosphorinane (5b): The above mother liquid was concentrated and the residue was recrystallized.from benzene-ether, $\mathrm{mp} 120-121^{\circ} \mathrm{C}$. Anal. Calcd for $\mathrm{C}_{6} \mathrm{H}_{13} \mathrm{O}_{3} \mathrm{P}: \mathrm{C}, 43.91 ; \mathrm{H}, 7.98$. Found: $\mathrm{C}, 43.66 ; \mathrm{H}, 7.93$. MS $m / z(\%): 164\left(\mathrm{M}^{+}, 2.3\right), 56(100)$. IR $v_{\max }^{\mathrm{KBr}} \mathrm{cm}^{-1}: 1475,1320,1255,1050,1010 . \mathrm{NMR}\left(\mathrm{CDCl}_{3}\right)$ $\delta: 1.00\left(3 \mathrm{H}, \mathrm{s}, \mathrm{CH}_{3}\right), 1.14\left(3 \mathrm{H}, \mathrm{s}, \mathrm{CH}_{3}\right), 1.58\left(3 \mathrm{H}, \mathrm{d}, J=20 \mathrm{~Hz}, \mathrm{PCH}_{3}\right), 3.77\left(2 \mathrm{H}, \mathrm{dd}, J=10,15 \mathrm{~Hz}, \mathrm{OCH}_{2}\right), 4.22(2 \mathrm{H}$, dd, $J=8,12 \mathrm{~Hz}, \mathrm{OCH}_{2}$ ).

Reaction of 2-Methoxy-1,3,2-dioxaphospholane (1c) with Bromoacetone-Method B: A mixture of bromoacetone $(5.48 \mathrm{~g}, 0.04 \mathrm{~mol})$ and $1 \mathrm{c}(4.88 \mathrm{~g}, 0.04 \mathrm{~mol})$ was stirred at room temperature, causing an exothermic reaction. After $20 \mathrm{~min}$, the reaction mixture was heated at $60-70^{\circ} \mathrm{C}$ for $1 \mathrm{~h}$, then chromatographed on silica gel (hexane-AcOEt) to afford $4 \mathrm{c}(1.15 \mathrm{~g}, 18 \%)$ and $6 \mathrm{cg}(4.34 \mathrm{~g}, 42 \%)$ as an oil.

2-Bromoethyl Methyl Acetonylphosphonate (6cg): bp $135-140{ }^{\circ} \mathrm{C}(1 \mathrm{mmHg})$. Anal. Calcd for $\mathrm{C}_{6} \mathrm{H}_{12} \mathrm{BrO}_{4} \mathrm{P}$. $1 / 2 \mathrm{H}_{2} \mathrm{O}: \mathrm{C}, 26.89 ; \mathrm{H}, 4.89$. Found: C, 26.80; H, 4.35. MS $m / z(\%): 259\left(\mathrm{M}^{+}, 0.9\right), 137(100) . \operatorname{IR} v_{\max }^{\text {film }} \mathrm{cm}^{-1}$ : 1710, 1255, NMR $\left(\mathrm{CDCl}_{3}\right) \delta: 2.34\left(3 \mathrm{H}, \mathrm{s}, \mathrm{COCH}_{3}\right), 3.15\left(2 \mathrm{H}, \mathrm{d}, J=23 \mathrm{~Hz}, \mathrm{PCH}_{2}\right), 3.55\left(2 \mathrm{H}, \mathrm{t}, J=6 \mathrm{~Hz}, \mathrm{CH}_{2} \mathrm{Br}\right)$, $3.82\left(3 \mathrm{H}, \mathrm{d}, J=11 \mathrm{~Hz}, \mathrm{POCH}_{3}\right), 4.31-4.46\left(2 \mathrm{H}, \mathrm{m}, \mathrm{POCH}_{2}\right)$.

2-Bromoethyl Methyl 2-Propenyl Phosphate (7cg): bp 116-120 ${ }^{\circ} \mathrm{C}(1 \mathrm{mmHg})$. An analytical sample was not obtained. MS $m / z(\%): 259\left(\mathrm{M}^{+}, 3.3\right), 113(100)$. IR $v_{\max }^{\mathrm{film}} \mathrm{cm}^{-1}: 1660,1280,1230,1030 . \mathrm{NMR}\left(\mathrm{CDCl}_{3}\right) \delta: 1.97(3 \mathrm{H}, \mathrm{s}$, $\left.=-\mathrm{CH}_{3}\right), 3.55\left(2 \mathrm{H}, \mathrm{t}, J=6 \mathrm{~Hz}, \mathrm{CH}_{2} \mathrm{Br}\right), 3.84\left(3 \mathrm{H}, \mathrm{d}, J=11 \mathrm{~Hz}, \mathrm{POCH}_{3}\right), 4.29-4.44\left(2 \mathrm{H}, \mathrm{m}, \mathrm{POCH}_{2}\right), 4.54(1 \mathrm{H}, \mathrm{br} \mathrm{s}$, $=\mathrm{CH}), 4.79(1 \mathrm{H}, \mathrm{t}, J=1 \mathrm{~Hz},=\mathrm{CH})$.

Reaction of 2-Methoxy-4,4,5,5-tetramethyl-1,3,2-dioxaphospholane (1d) with Bromoacetone - A mixture of bromoacetone $(4.11 \mathrm{~g}, 0.03 \mathrm{~mol})$ and $1 \mathrm{~d}(5.34 \mathrm{~g}, 0.03 \mathrm{~mol})$ was stirred at room temperature, causing an exothermic reaction. After $30 \mathrm{~min}$, the reaction mixture was heated at $60^{\circ} \mathrm{C}$ for $30 \mathrm{~min}$, and the temperature then rose to $100^{\circ} \mathrm{C}$. When the evolution of methyl bromide gas had almost ceased, the mixture was kept at $60^{\circ} \mathrm{C}$ for $30 \mathrm{~min}$. The reaction mixture was chromatographed on silica gel (hexane-AcOEt) to afford $3 \mathrm{~d}(3.52 \mathrm{~g}, 53 \%)$ and $\mathbf{4 d}(1.48 \mathrm{~g}, 22 \%)$ as oils.

2-Acetonyl-4,4,5,5-tetramethyl-2-oxo-1,3,2-dioxaphospholane $\left.(3 \mathrm{~d})^{4}\right)$ : bp $151-153^{\circ} \mathrm{C}(0.5 \mathrm{mmHg}), \mathrm{mp} 54-$ $56^{\circ} \mathrm{C}$ (from iso- $\mathrm{Pr}_{2} \mathrm{O}$ ).

4,4,5,5-Tetramethyl-2-oxo-2-(2-propenyloxy)-1,3,2-dioxaphospholane (4d): bp 116-119 ${ }^{\circ} \mathrm{C}(1 \mathrm{mmHg})$, an unstable oil. Anal. Calcd for $\mathrm{C}_{9} \mathrm{H}_{17} \mathrm{O}_{4} \mathrm{P} \cdot 1 / 2 \mathrm{H}_{2} \mathrm{O}: \mathrm{C}, 47.20 ; \mathrm{H}, 7.92$. Found: C, 47.23; H, 7.52. $\mathrm{MS} \mathrm{m} / z(\%): 220\left(\mathrm{M}^{+}, 9.8\right)$, 43 (100). IR $v_{\max }^{\mathrm{film}} \mathrm{cm}^{-1}: 1660,1295,1145$. NMR $\left(\mathrm{CDCl}_{3}\right) \delta: 1.44\left(6 \mathrm{H}, \mathrm{s}, 2 \times \mathrm{CH}_{3}\right), 1.48\left(6 \mathrm{H}, \mathrm{s}, 2 \times \mathrm{CH}_{3}\right), 1.97(3 \mathrm{H}, \mathrm{s}$, $\left.=-\mathrm{CH}_{3}\right), 4.52(1 \mathrm{H}$, br s, $=\mathrm{CH}), 4.76(1 \mathrm{H}, \mathrm{t}-$ like, $=\mathrm{CH})$.

Reaction of 2-Methoxy-4,7-dihydro-1,3,2-dioxaphosphepin (1e) with Bromoacetone-A mixture of bromoacetone $(1.37 \mathrm{~g}, 0.01 \mathrm{~mol})$ and $1 \mathrm{e}(1.48 \mathrm{~g}, 0.01 \mathrm{~mol})$ was stirred at $10^{\circ} \mathrm{C}$, causing an exothermic reaction. After $30 \mathrm{~min}$ the temperature rose to $100^{\circ} \mathrm{C}$. The mixture was kept at $60^{\circ} \mathrm{C}$ for an additional $30 \mathrm{~min}$. The reaction mixture was chromatographed on silica gel (hexane-AcOEt) to afford $3 \mathrm{e}(0.37 \mathrm{~g}, 10 \%), 6 \mathrm{eg}(0.99 \mathrm{~g}, 17 \%)$ and $7 \mathrm{eg}(0.15 \mathrm{~g}, 3 \%)$ as an oil.

2-Acetonyl-2-oxo-4,7-dihydro-1,3,2-dioxaphosphepin (3e) $)^{4}$ : bp $150-153^{\circ} \mathrm{C}(0.5 \mathrm{mmHg})$.

4-Bromo-2-butenyl Methyl Acetonylphosphonate (6eg): bp $158-162^{\circ} \mathrm{C}(0.6 \mathrm{mmHg})$; partial decomposition occurred when 6eg was distilled, so no an analytical sample was obtained. MS $m / z(\%): 205$ (65.2), 135 (100). IR $v_{\max }^{\mathrm{film}} \mathrm{cm}^{-1}: 1710,1350 . \mathrm{NMR}\left(\mathrm{CDCl}_{3}\right) \delta: 2.33\left(3 \mathrm{H}, \mathrm{s}, \mathrm{CH}_{3}\right), 31.2\left(2 \mathrm{H}, \mathrm{d}, J=22 \mathrm{~Hz}, \mathrm{PCH}_{2}\right), 3.79(3 \mathrm{H}, \mathrm{d}, J=11 \mathrm{~Hz}$, 
$\left.\mathrm{POCH}_{3}\right), 4.01\left(2 \mathrm{H}, \mathrm{d}, \mathrm{J}=8 \mathrm{~Hz}, \mathrm{CH}_{2} \mathrm{Br}\right), 4.68-4.78\left(2 \mathrm{H}, \mathrm{m}, \mathrm{OCH}_{2}\right), 5.68-5.81(1 \mathrm{H}, \mathrm{m}, \mathrm{CH}=), 5.90-6.07(1 \mathrm{H}, \mathrm{m}$, $\mathrm{CH}=$ ).

4-Bromo-2-butenyl Methyl 2-Propenyl Phosphate (7eg): MS $m / z(\%): 205$ (12.9), 99 (100). IR $v_{\max }^{\mathrm{film}} \mathrm{cm}^{-1}$ : 1650, 1280. NMR $\left(\mathrm{CDCl}_{3}\right) \delta: 2.00\left(3 \mathrm{H}, \mathrm{s}, \mathrm{CH}_{3}\right), 3.83\left(3 \mathrm{H}, \mathrm{d}, J=10 \mathrm{~Hz}, \mathrm{OCH}_{3}\right), 4.50-4.88(6 \mathrm{H}, \mathrm{m}$, $\left.2 \times \mathrm{CH}_{2}+=\mathrm{CH}_{2}\right), 5.79(2 \mathrm{H}, \mathrm{t}, J=1.5 \mathrm{~Hz}, \mathrm{CH}=\mathrm{CH})$.

Reaction of 1a with Chloroacetone-A mixture of chloroacetone $(1.84 \mathrm{~g}, 0.02 \mathrm{mmol})$ and $1 \mathrm{e}(2.72 \mathrm{~g}, 0.02 \mathrm{~mol})$ was stirred at room temperature. The reaction mixture was heated at $70^{\circ} \mathrm{C}$ for $2 \mathrm{~h}$, then chromatographed on silica gel (hexane-AcOEt) to afford $4 \mathrm{a}(2.50 \mathrm{~g}, 70 \%)$ and $7 \mathrm{ag}(0.64 \mathrm{~g}, 14 \%)$.

3-Chloropropyl Methyl 2-Propenyl Phosphate (7ah): Anal. Calcd for $\mathrm{C}_{7} \mathrm{H}_{14} \mathrm{ClO}_{4} \mathrm{P} \cdot 1 / 2 \mathrm{H}_{2} \mathrm{O}: \mathrm{C}, 35.38 ; \mathrm{H}, 6.36$. Found: C, 35.79; H, 6.03. MS $m / z(\%): 228\left(\mathrm{M}^{+}, 6.4\right), 113(100)$. IR $v_{\max }^{\text {film }} \mathrm{cm}^{-1}: 1660,1285$. NMR $\left(\mathrm{CDCl}_{3}\right) \delta: 1.96$ $\left(3 \mathrm{H}, \mathrm{s},=\mathrm{C}-\mathrm{CH}_{3}\right), 2.06-2.24\left(2 \mathrm{H}, \mathrm{m}, \mathrm{CH}_{2}\right), 3.66\left(2 \mathrm{H}, \mathrm{t}, J=6 \mathrm{~Hz}, \mathrm{CH}_{2} \mathrm{Cl}\right), 3.83\left(3 \mathrm{H}, \mathrm{d}, J=11 \mathrm{~Hz}, \mathrm{POCH}_{3}\right), 4.26(2 \mathrm{H}$, dd, $\left.J=6,14 \mathrm{~Hz}, \mathrm{POCH}_{2}\right), 4.52(1 \mathrm{H}, \mathrm{s},=\mathrm{CH}), 4.77(1 \mathrm{H}, \mathrm{t}, J=1 \mathrm{~Hz},=\mathrm{CH})$.

Reaction of $1 \mathrm{a}$ with Iodoacetone-A mixture of iodoacetone $(5.52 \mathrm{~g}, 0.03 \mathrm{~mol})$ and $1 \mathrm{a}(4.08 \mathrm{~g}, 0.03 \mathrm{~mol})$ was stirred at $5{ }^{\circ} \mathrm{C}$, causing an exothermic reaction; after $20 \mathrm{~min}$ the reaction temperature rose to $80^{\circ} \mathrm{C}$. The mixture was treated as described in method B. Chromatography gave a mixture $(3.32 \mathrm{~g})$ of $3 \mathrm{a}$ and $\mathbf{5 a}(51 \%$ and $15 \%$, respectively) as an oil, $4 \mathrm{a}(0.49 \mathrm{~g}, 9 \%)$ and a mixture $(0.86 \mathrm{~g})$ of $6 \mathrm{ai}$ and $8 \mathrm{ai}(8 \%$ and $1 \%$, respectively).

3-Iodopropyl Methyl Acetonylphosphonate (6ai): bp 138-140 ${ }^{\circ} \mathrm{C}(0.5 \mathrm{mmHg}) . \mathrm{MS} \mathrm{m} / z(\%): 320$ (M $\left.\mathbf{M}^{+}, 0.7\right), 193$ (100). IR $v_{\max }^{\text {film }} \mathrm{cm}^{-1}: 1710,1355$. NMR $\left(\mathrm{CDCl}_{3}\right) \delta: 2.16\left(2 \mathrm{H}, \mathrm{m}, \mathrm{CH}_{2}\right), 2.34\left(3 \mathrm{H}, \mathrm{s}, \mathrm{CH}_{3}\right), 3.12(2 \mathrm{H}, \mathrm{d}, J=24 \mathrm{~Hz}$, $\left.\mathrm{PCH}_{2}\right), 3.26\left(2 \mathrm{H}, \mathrm{t}, J=7 \mathrm{~Hz}, \mathrm{CH}_{2} \mathrm{I}\right), 3.82\left(3 \mathrm{H}, \mathrm{d}, J=12 \mathrm{~Hz}, \mathrm{POCH}_{3}\right), 4.18\left(2 \mathrm{H}, \mathrm{m}, \mathrm{OCH}_{2}\right)$.

3-Iodopropyl Methyl Methylphosphonate (8ai)_A mixture of $1 \mathrm{a}(1.36 \mathrm{~g}, 0.01 \mathrm{~mol})$ and methyl iodide $(2.8 \mathrm{~g}$, $0.02 \mathrm{~mol}$ ) was stirred for $2 \mathrm{~h}$ at room temperature, then refluxed for $2 \mathrm{~h}$. The reaction mixture was concentrated, and the residue was crystallized from ether. The crystals $(1.06 \mathrm{~g}, 88 \%: 5 \mathrm{a})$ were collected by filtration, and the filtrate was concentrated. The residue was chromatographed on silica gel to give 8 ai $(0.218 \mathrm{~g}, 8 \%)$ as an oil. Anal. Calcd for $\mathrm{C}_{5} \mathrm{H}_{12} \mathrm{IO}_{3} \mathrm{P}: \mathrm{C}, 21.60 ; \mathrm{H}, 4.35$. Found: $\mathrm{C}, 21.45 ; \mathrm{H}, 4.18$. IR $v_{\max }^{\text {film }} \mathrm{cm}^{-1}: 1310,1240,1180,1030 . \mathrm{NMR}\left(\mathrm{CDCl}_{3}\right) \delta: 1.50$ $\left(3 \mathrm{H}, \mathrm{d}, J=18 \mathrm{~Hz}, \mathrm{CH}_{3}\right), 2.08-2.25\left(2 \mathrm{H}, \mathrm{m}, \mathrm{CH}_{2}\right), 3.75\left(3 \mathrm{H}, \mathrm{d}, J=11 \mathrm{~Hz}, \mathrm{POCH}_{3}\right), 4.04-4.20\left(2 \mathrm{H}, \mathrm{m}_{,} \mathrm{POCH}_{2}\right)$.

Reaction of 2-Benzyloxy-1,3,2-dioxaphosphorinane (1f) with Bromoacetone $\mathrm{A}$ mixture of bromoacetone $(2.74 \mathrm{~g}, 0.02 \mathrm{~mol})$ and $1 \mathrm{f}(4.24 \mathrm{~g}, 0.02 \mathrm{~mol})$ was stirred at room temperature; after $20 \mathrm{~min}$ the reaction temperature rose to $50^{\circ} \mathrm{C}$. The mixture was kept at $70^{\circ} \mathrm{C}$ for $1 \mathrm{~h}$ and chromatographed on silica gel to give $4 \mathrm{a}(1.47 \mathrm{~g}, 41 \%)$ and a mixture $(1.84 \mathrm{~g})$ of $3 \mathrm{a}$ and $9(37 \%$ and $12 \%$, respectively). The mixture was crystallized from ether to give $9(0.28 \mathrm{~g}$, recrystallized from AcOEt).

2-Benzyloxy-2-oxo-1,3,2-dioxaphosphorinane (9): mp 136-138 ${ }^{\circ} \mathrm{C}$. Anal. Calcd for $\mathrm{C}_{10} \mathrm{H}_{13} \mathrm{O}_{3} \mathrm{P}: \mathrm{C}, 56.60 ; \mathrm{H}$, 6.18. Found: C, 56.47; H, 6.30. IR $v_{\max }^{\mathrm{KBr}} \mathrm{cm}^{-1}: 1495,1290,1050 . \mathrm{NMR}\left(\mathrm{CDCl}_{3}\right) \delta: 1.60-1.99\left(2 \mathrm{H}, \mathrm{m}, \mathrm{CH}_{2}\right), 3.26(2 \mathrm{H}$, d, $\left.J=20 \mathrm{~Hz}, \mathrm{PCH}_{2}\right), 3.94-4.18\left(2 \mathrm{H}, \mathrm{m}, \mathrm{POCH}_{2}\right), 4.35-4.54\left(2 \mathrm{H}, \mathrm{m}, \mathrm{POCH}_{2}\right), 7.20-7.40(5 \mathrm{H}, \mathrm{m}, \mathrm{ArH})$.

\section{References}

1) W. Perkow, K. Ullerich, and F. Meyer, Naturwissenschaften, 39, 353 (1952) [Chem. Abstr., 47, 8248 (1953)]; F. W. Lichtenthaler, Chem. Rev., 61, 607 (1961).

2) A. E. Arbuzov, J. Russ. Phys. Chem. Soc., 38, 687 (1906); A. N. Pudovik, Dokl. Akad. Nauk SSSR, 105, 735 (1955) [Chem. Abstr., 50, $4143 f(1956)]$; H. I. Jacobsen, M. J. Griffin, S. Preis, and E. V. Jensen, J. Am. Chem. Soc., 79, 1608 (1957); A. K. Bhattacharya and G. Thyagarajan, Chem. Rev., 81, 415 (1981).

3) L. Horner, H. Hoffmann, and H. G. Wippel, Chem. Ber., 91, 61 (1958); W. S. Wadsworth, J. Am. Chem. Soc., 83, 1733 (1961).

4) I. Morita, S. Tada, K. Kunimoto, M. Tsuda, M. Kise, and K. Kimura, Chem. Pharm. Bull., 35, 3898 (1987).

5) I. Morita, K. Kunimoto, M. Tsuda, S. Tada, M. Kise, and K. Kimura, Chem: Pharm. Bull., 35, 4144 (1987).

6) G. Aksnes and R. Erikson, Acta Chem. Scand., 20, 2463 (1966) [Chem. Abstr., 67, 21304a (1967)]; R. F. Hudson and R. Greenhalgh, J. Chem. Soc., Chem. Commun., 1968, 1300.

7) P. A. Chopard, V. M. Clark, R. F. Hudson, and A. J. Kirby, Tetrahedron, 21, 1961 (1965) and references cited therein.

8) I. J. Borowitz, S. Firstenberg, G. B. Borowitz, and D. Schuessler, J. Am. Chem. Soc., 94, 1623 (1972).

9) P. Gillespie, F. Ramirez, I. Ugi, and D. Marquarding, Angew. Chem., Int. Ed. Engl., 12, 91 (1973). 